Jurnal Progres Ekonomi Pembangunan (JPEP)

Volume 4, Nomor 2, Tahun 2019

Page: 67-80

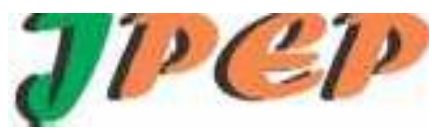

http://ojs.uho.ac.id/index.php/JPEP

\title{
ANALISIS PENGARUH INVESTASI DAN TENAGA KERJA TERHADAP PERTUMBUHAN EKONOMI ANTAR PROVINSI DI INDONESIA
}

\author{
Muhamad Tasrif ${ }^{1)}$ \\ Program Pascasarjana Universitas Haluoleo, Kendari \\ Rosnawintang ${ }^{2)}$ danManat Rahim ${ }^{2)}$ \\ ${ }^{2}$ ) Fakultas Ekonomi dan Bisnis Universitas Haluoleo
}

\begin{abstract}
ABSTRAK
Penelitian ini bertujuan untuk mengetahui dan menganalisis pengaruh investasi dan tenaga kerja terhadap pertumbuhan ekonomi antar Provinsi di Indonesia Periode 2011 sampai 2017. Jenis penelitian ini merupakan penelitian kuantitatif dengan menggunakan data sekunder. Model analisis yang dipakai dalam penelitian adalah analisis regresi data panel dengan menggunakan Random Effect Models (REM), dan diolah menggunakan E-views 10. Penelitian ini dilakukan di 33 Provinsi Indonesia.

Hasil penelitian ini menunjukan bahwa, (1) variabel investasi berpengaruh signifikan dan positif terhadap pertumbuhan ekonomi antar Provinsi di Indonesia, artinya peningkatan investasi mampu memberikan dampak terhadap peningkatan pertumbuhan ekonomi, semakin bertambah investasi maka pertumbuhan ekonomi semakin meningkat (2) variabel tenaga kerja berpengaruh signifikan dan positif terhadap pertumbuhan ekonomi antar Provinsi di Indonesia, artinya perkembangan peningkatan tenaga kerja mampu memberikan dampak terhadap peningkatan pertumbuhan ekonomi, semakin bertambah tenaga kerja maka pertumbuhan ekonomi mengalami peningkatan.
\end{abstract}

\section{Kata Kunci: Pertumbuhan Ekonomi, Investasi, Tenaga Kerja}

\section{PENDAHULUAN}

Suatu perekonomian dikatakan mengalami pertumbuhan ekonomi jika jumlah produksi barang dan jasanya meningkat, olehnya itu persoalan ekonomi merupakan hal yang sangat penting dalam masyarakat. Hal ini selaras dengan apa yang disampaikan (Sukirno, 2012:49), bahwa dengan mengamati tingkat pertumbuhan ekonomi yang tercapai dari tahun ke tahun dapatlah dinilai prestasi dan kesuksesan negara tersebut dalam mengendalikan kegiatan ekonominya dalam jangka pendek dan usaha mengembangkan perekonomian dalam jangka panjang.

Berdasarkan data statistik, dimana perkembangan pertumbuhan ekonomi dalam lima tahun terakhir ini, mulai tahun 2013-2017 mengalami perkembangan yang berfluktuasi, hal ini dapat kita lihat pada data statistik dimana pertumbuhan tahun 2015 yaitu sebesar 4,88\%, pertumbuhan tersebut mengalami penurunan bila dibandingkan pada tahun sebelumnya dimana tahun 2014 pertumbuhan ekonomi yaitu sebesar 5,01\%. Selanjutnya pertumbuhan ekonomi kembali mengalami peningkatan sampai pada tahun 2017, dimana pertumbuhan ekonomi tahun 2017 yaitu sebesar $5,07 \%$.

Perkembangan pertumbuhan ekonomi nasional ini tentunya sangat ditentukan dengan perkembangan pembangunan ekonomi di berbagai daerah, olehnya itu pentingnya peranan daerah dalam melihat berbagai hal-hal yang dapat meningkatkan pertumbuhan ekonomi di daerah masing-masing. 
Jurnal Progres Ekonomi Pembangunan (JPEP)

Volume 4, Nomor 2, Tahun 2019

Page: 67-80

http://ojs.uho.ac.id/index.php/JPEP

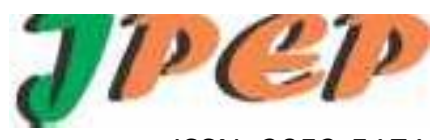

e-ISSN: 2052-5171

Tabel 1.1. Perkembangan Pertumbuhan Ekonomi Provinsi di Indonesia Menurut Kelompok Pulau Tahun 2013-2017.

\begin{tabular}{|c|c|c|c|c|c|c|}
\hline \multirow{2}{*}{ Wilayah } & \multicolumn{5}{|c|}{ Pertumbuhan ekonomi } & \multirow{2}{*}{ Rat-rata } \\
\cline { 2 - 6 } & 2013 & 2014 & 2015 & 2016 & 2017 & \\
\hline Sumatra & 4,95 & 4,59 & 3,53 & 4,29 & 4,30 & 4,33 \\
\hline Jawa & 6,01 & 5,57 & 5,48 & 5,60 & 5,61 & 5,66 \\
\hline Bali dan Nusa Tenggara & 5,95 & 5,90 & 10,42 & 5,92 & 3,73 & 6,38 \\
\hline Kalimantan & 2,95 & 3,37 & 1,38 & 2,02 & 4,33 & 3,01 \\
\hline Sulawesi & 7,69 & 6,87 & 8,19 & 7,43 & 6,99 & 7,43 \\
\hline Kep. Maluku dan Papua & 7,71 & 4,54 & 6,28 & 7,40 & 4,89 & 6,17 \\
\hline
\end{tabular}

Sumber: BPS (data diolah)

Berdasarkan Tabel 1.1, dalam lima tahun terakhir ini, rata-rata pertumbuhan ekonomi di Indonesia di tiap-tiap pulau sangat bervariasi dan juga mengalami perkembangan pertumbuhan yang berfluktuasi, hal ini dapat kita lihat pada tabel 1.1, dimana untuk rata-rata pertumbuhan ekonomi dalam lima tahun terakhir ini, tiga wilayah yang memiliki rata-rata pertumbuhan diatas 6\%, yaitu pulau Sulawesi, Kepulauan Bali dan Nusa Tenggara, dan Kepulauan Maluku dan Papua.

Sementara untuk rata-rata pertumbuhan terendah mulai 2013-2017 yaitu wilayah Kalimantan dengan rata-rata pertumbuhan ekonomi sebesar 3,01\%, sedangkan untuk wilayah Jawa rata-rata pertumbuhan dalam lima tahun ini sebesar 5,66\% dan untuk wilayah Sumatra, rata-rata pertumbuhannya sebesar $4,33 \%$.

Menurut Harrord Domard (Rahardja, Manurung, 2008: 143), salah satu faktor yang mempengaruhi pertumbuhan ekonomi yaitu investasi, sebab investasi ini akan meningkatkan stok barang modal, yang pada akhirnya memungkinkan peningkatan output. Olehnya itu investasi mempunyai pengaruh positif dan sangat mempengaruhi pertumbuhan ekonomi. Penjelasan tersebut sejalan dengan hasil penelitian yang dilakukan oleh Pambudi. E,Wicaksono (2013) dimana hasil penelitianya menunjukan bahwa investasi berpengaruh positif dan signifikan terhadap pertumbuhan ekonomi.

Selanjutnya faktor lain yang mempengaruhi pertumbuhan ekonomi adalah tenaga kerja. Menurut kajian teori Adam Smith (Murni. Asfia, 2016: 195), bahwa peningkatan output akan berkembang sejalan perkembangan penduduk, artinya pertambahan penduduk merupakan salah satu faktor yang dapat meningkatkan pertumbuhan ekonomi. Jumlah tenga kerja yang lebih besar akan menambah jumlah tenaga kerja produktif, semakin besar tenaga kerja produktif maka output yang dihasilkan juga semakin besar. Teori tersebut sejalan dengan penelitian Sari. T. Irmaya (2017), dimana hasil penelitiannya menjelaskan bahwa variabel tenaga kerja berpengaruh positif dan signifikan terhadap pertumbuhan ekonomi.

Berdasarkan uraian diatas, maka peneliti tertarik untuk melakukan penelitian dengan judul: Analisis Pengaruh Investasi dan Tenaga Kerja Terhadap Pertumbuhan Ekonomi Antar Provinsi di Indonesia.

\section{Rumusan Masalah}

Berdasarkan latar belakang diatas, maka untuk permasalahan yang akan dipecahkan dalam penelitian ini yaitu sebaga berikut:

1. Apakah investasi berpengaruh terhadap pertumbuhan ekonomi antar Provinsi di Indonesia? 
Jurnal Progres Ekonomi Pembangunan (JPEP)

Volume 4, Nomor 2, Tahun 2019

Page: $67-80$

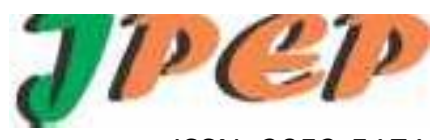

http://ojs.uho.ac.id/index.php/JPEP

2. Apakah tenaga kerja berpengaruh terhadap pertumbuhan ekonomi antar Provinsi di Indonesia.

\section{Tujuan penelitian}

Adapun tujuan dari penelitian ini adalah sebagai berikut:

1. Untuk mengetahui dan menganalisis pengaruh investasi terhadap pertumbuhan ekonomi antar Provinsi di Indonesia.

2. Untuk mengetahui dan menganalisis pengaruh tenaga kerja terhadap pertumbuhan ekonomi antar Provinsi di Indonesia.

\section{Manfaat Penelitian}

Adapun manfaat dari penelitian adalah sebagai berikut:

1. Secara teoritis

Hasil penelitian ini diharapkan dapat memperluas pengetahuan, memberikan tambahan referensi bagi perkembangan ilmu pengetahuan, dan menambah wawasan dasar mengenai pengaruh investasi, tenaga kerja dan tenaga kerja terhadap pertumbuhan ekonomi.

2. Secara praktis

a. Penelitian ini dapat bermanfaat bagi penulis maupun pembaca dalam hal penambahan ilmu pengetahuan dan wawasan terkait dengan persoalan pertumbuhan ekonomi.

b. Penelitian ini dapat bermanfaat pemerintah dalam merumuskan persoalan khususnya berkaitan dengan masalah pertumbuhan ekonomi.

\section{Kebaruan Penelitian}

Berkaitan dengan Penelitian yang berhubungan dengan pertumbuhan ekonomi, tentunya sudah banyak peneliti yang melakukan penelitian yang membahan tentang pertumbuhan ekonomi, namun untuk kebaruan dalam penelitian ini yaitu sebagai berikut:

1. Variabel investasi yang digunakan pada penelitian ini yaitu penanaman modal tetap bruto bangunan (PMTB bangunan).

2. Variabel tenaga kerja yang dimaksud dalam penelitian ini yaitu tenaga kerja yang golongan bekerja.

\section{TINJAUANPUSTAKA}

\section{Pengaruh Investasi Terhadap Pertumbuhan Ekonomi}

Pertumbuhan ekonomi merupakan gambaran dari perkembangan perekonomian suatu negara atau daerah. Menurut Sukirno (2012:9), pertumbuhan ekonomi adalah perkembangan kegiatan dalam perekonomian yang menyebabkan barang dan jasa yang diproduksikan dalam masyarakat bertambah. Langkah untuk peningkatan produksi barang dan jasa bisa dilakukan dengan penambahan faktor-faktor produksi, misalnya penambahan tenaga kerja, peningkatan tekhnologi dengan pembelian mesin-mesin produksi dengan tujuan untuk peningkatan produksi barang dan jasa, hal ini disebut juga sebagai investasi.

Menurut teori Schumpeter berpandangan bahwa yang mempengaruhi pertumbuhan ekonomi sangatlah ditentukan oleh kemampuan kewirausahaan (Rahardja, Manurung, 2008: 143). Sebab, para pengusahalah yang mempunyai keberanian dan kemampuan mengaplikasi penemuan-penemuan baru dalam aktifitas produksi. Langkah-langkah pengaplikasian penemuan-penemuan baru didalam dunia usaha merupakan langkah inovasi. Termasuk dalam langkah-langkah inovasi adalah penyusunan teknik tahap produksi serta masalah organisasi manajemen, agar produk yang dihasilkan dapat diterima pasar.

Keputusan perusahan-perusahaan untuk meningkatkan stok barang modal dapat memberikan dampak positif terhadap total perekonomian, sebab peningkatan stok barang modal secara nasional akan dapat meningkatkan kegiatan produksi dan juga memperluas kesempatan kerja (Rahardja, Manurung,2008: 71). 
Jurnal Progres Ekonomi Pembangunan (JPEP)

Volume 4, Nomor 2, Tahun 2019

Page: 67-80

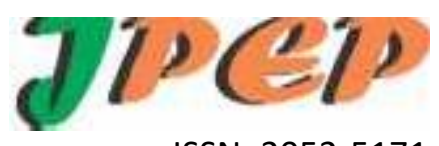

http://ojs.uho.ac.id/index.php/JPEP

e-ISSN: 2052-5171

Lebih lanjut didalam Teori Harrod-Domar menjelaskan bahwa investasi merupakan hal yang penting untuk pertumbuhan ekonomi, sebab investasi akan meningkatkan stok barang

modal, yang pada akhirnya memungkinkan peningkatan output, (Rahardja, Manurung, 2008:143)

\section{Pengaruh Tenaga Kerja Terhadap Pertumbuhan Ekonomi}

Tenaga kerja merupakan salah satu unsur penting dalam usaha meningkatkan produksi atau output. Menurut teori kaum klasik salah satu faktor yang mempengaruhi pertumbuhan ekonomi adalah jumlah penduduk. Menurut penjelasan Adam Smith (Murni. Asfia, 2016: 195), bahwa peningkatan output akan berkembang sejalan perkembangan penduduk, artinya pertambahan penduduk merupakan salah satu faktor yang dapat meningkatkan pertumbuhan ekonomi.

Dalam Teori Penduduk Optimum dimana teori ini juga merupakan teori pertumbuhan ekonomi klasik yang menjelaskan bahwa pertambahan total produk itu akan terjadi jika pertambahan tenaga kerja diikuti dengan pertambahan modal artinya dalam teori ini menjelaskan bahwa tenaga kerja merupakan salah satu unsur yang dapat meningkatkan pertumbuhan ekonomi (Murni. A, 2016: 195).

Dari uraian diatas dapat disumpulkan bahwa penduduk berpengaruh positif terhadap pertumbuhan ekonomi, artinya peningkatan jumlah penduduk akan juga dapat meningkatkan pertumbuhan ekonomi.

\section{Kerangka Konsep}

Berdasarkan teori-teori pertumbuhan ekonomi yang diuraikan dan riset-riset terdahulu, dimana bahwa adanya pengaruh perkembangan investasi dan tenaga kerja terhadap pertumbuhan ekonomi. Dengan demikian maka untuk gambar kerangka kosepnya sebaga berikut:

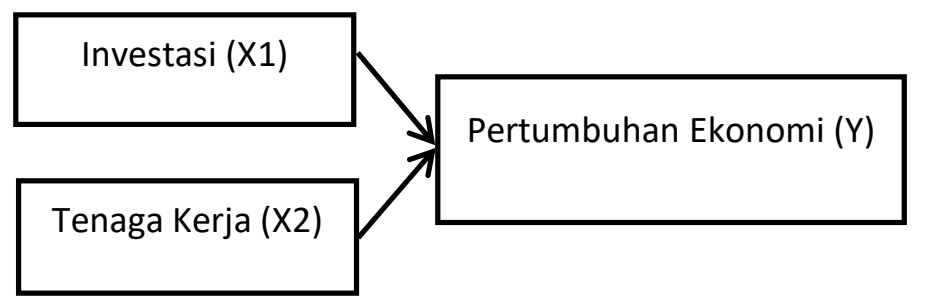

\section{Gambar: Kerangka Konsep}

\section{Hipotesis Penelitian}

\section{Pengaruh Investasi Terhadap Pertumbuhan Ekonomi}

Teori Harrord Domar menjelaskan bahwa perkembangan Investasi mempunyai pengaruh terhadap pertumbuhan ekonomi, sebab investasi ini akan meningkatkan stok barang modal, yang pada akhirnya memungkinkan untuk peningkatan output, artinya peningkatan investasi akan memberikan dampak terhadap peningkatan pertumbuhan ekonomi. Hasil penelitian yang dilakukan oleh Ginting. Ari. Mulianta (2017), Sari.T. Irmaya (2017), dan I Made Yudisthira, I Gede Sujana Budhiasa (2012) yang menemukan bahwa investasi berpengaruh positif dan signifikan terhadap pertumbuhan ekonomi.

H1 = Diduga variabel investasi berpengaruh signifikan dan positif terhadap pertumbuhan ekonomi antar provinsi di Indonesia.

\section{Pengaruh Tenaga Kerja Terhadap Pertumbuhan Ekonomi}


Jurnal Progres Ekonomi Pembangunan (JPEP)

Volume 4, Nomor 2, Tahun 2019

Page: 67-80

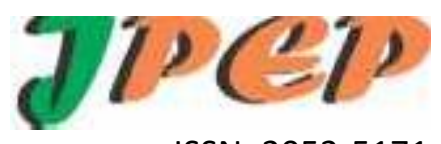

http://ojs.uho.ac.id/index.php/JPEP

Teori kaum klasik berpendapat bahwa salah satu faktor yang dapat mempengaruhi pertumbuhan ekonomi adalah jumlah penduduk. Teori pertumbuhan ekonomi klasik ini yang menjelaskan bahwa pertambahan total produk itu akan terjadi jika pertambahan tenaga kerja diikuti dengan pertambahan. Teori ini sejalan dengan penelitian yang dilakukan oleh Surtoyo, Yesi. H (2013), Sari. T. Irmaya (2015) yang hasil penelitianya bahwa tenaga kerja berpengaruh positif dan signifikan terhadap pertumbuhan ekonomi.

H2 = Diduga variabel tenaga kerja berpengaruh signifikan dan positif terhadap pertumbuhan ekonomi antar provinsi di Indonesia

\section{METODE PENELITIAN}

Penelitian ini merupakan penelitian eksplanasi (explanatory research) yaitu penelitian yang bertujuan untuk menguji atau menjelaskan hubungan antar variabel yang dihipotesiskan.

\section{Defenisi Operasional Variabel}

Untuk memudahkan pemahaman terhadap istilah dari variabel yang digunakan dalam penelitian ini, maka perlu diberikan batasan operasional sebagai berikut:

1. Pertumbuhan ekonomi

Pertumbuhan ekonomi yang dimaksud dalam penelitian ini adalah jumlah dari pertumbuhan output barang dan jasa (pertumbuhan nominal PDRB) di masing-masing Provinsi di Indonesia yang diukur atas dasar harga konstan yang dinyatakan dalam bentuk rupiah (Rp).

2. Investasi

Investasi yang dimaksud atau digunakan dalam penelitian ini adalah jumlah Penanaman Modal Tetap Bruto (PMTB) bangunan di seluruh Provinsi di Indonesia yang diukur berdasarkan atas dasar harga konstan yang dinyatakan dengan rupiah $(\mathrm{Rp})$.

3. Tenaga kerja

Tenaga kerja yang dimaksud dalam penelitian ini adalah jumlah dari keseluruhan tenaga kerja ya ng golongan bekerja seluruh Provinsi di Indonesia yang diukur berdasarkan atas dasar harga konstan yang dinyatakan dalam satuan orang.

\section{Metode Analisis}

Metode analis yang digunakan dalam penelitian ini yaitu menggunakan analisis panel data (pooled data) dengan bantuan program aplikasi E-views 6. Yang dimaksud dengan data panel adalah gabungan antara data runtut waktu atau time series dan data silang atau cross section. Dalam model data panel persamaan model menggunakan data cross-section dapat ditulis sebagai berikut:

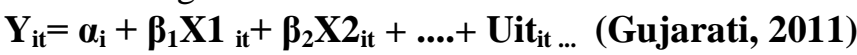

berikut:

Model tersebut akan diaplikasikan pada penelitian ini dengan persamaan sebagai

$\operatorname{LogPE}_{\mathrm{it}}=\alpha_{\mathrm{i}}+\beta_{1} \operatorname{LogIN} \mathrm{it}_{\mathrm{it}}+\mathrm{B}_{2} \operatorname{LogTK} \mathrm{K}_{\mathrm{it}}+\mathrm{Uit}_{\mathrm{it}}$

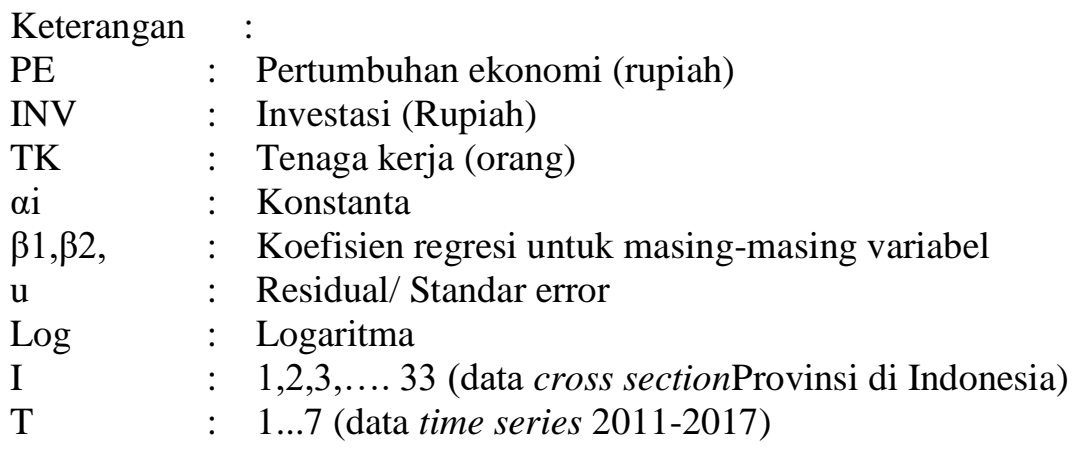


Jurnal Progres Ekonomi Pembangunan (JPEP)

Volume 4, Nomor 2, Tahun 2019

Page: $67-80$

http://ojs.uho.ac.id/index.php/JPEP

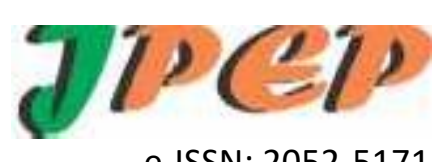

e-ISSN: 2052-5171

\section{HASIL DAN PEMBAHASAN}

\section{Hasil regresi data panel}

Uji Chow

Uji Chow digunakan untuk memilih model estimasi common effect atau model estimasi fixed effect,yang tepatdengan hipotesis sebagai berikut:

H0 : memilih menggunakan model estimasi Common Effect.

H1 : memilih menggunakan model estimasi Fixed Effect.

Dalam pengujian ini dapat dilihat nilai $p$-value jika hasil yang didapatkan kurang dari $\alpha$ $5 \%$ (signifikan) maka model estimasi yang akan digunakan adalah fixed effect, akan tetapi jika $p$-value melebihi dari angka $\alpha 5 \%$ (tidak signifikan) dengan demikian model estimasi yang dipilihdalam penelitian ini adalah model common effect.

Tabel 5.8 uji chow

Test cross-seaction fixed effects

\begin{tabular}{llll}
\hline Effects Test & Statistic & d.f & prob \\
\hline Cross-section F & 3.518367 & $(32,196)$ & 0.0000 \\
Cross-section Chi-square & 104.848961 & 32 & 0,0000 \\
\hline
\end{tabular}

\section{Sumber: Data diolah E-views 10}

Dari hasil Tabel 5.8, nilai yang dihasilkan dalam distribusi statistik terhadap chi square berdasarkan hasil hitung dengan menggunakan eviews 10 adalah sebesar 104.848961 dengan probabilitas yang dihasilkan 0,0000 yaitu menyatakan signifikan karena $<0,05$, sehingga statistik yang terjadi menerima $\mathrm{H} 1$ dan menolak $\mathrm{H} 0$, dimana dalam hal ini pemilihan model yang tepat untuk digunakan yaitu model fixed effect.

\section{Uji Lagrange Multiplier Test}

Uji ini digunkan untuk membandikan atau memilih model yang terbaik antara model Comon maupun model RandomEffect. Kriteria pengujian dalam pengujian ini sebagai berikut :

H0 : memilih menggunakan model estimasi Common Effect.

H1 : memilih menggunakan model estimasi Random effect

Tabel 5.9 Hasil Uji Lagrange Multiplier

\begin{tabular}{lccl}
\hline \hline $\begin{array}{l}\text { Null (no rand. effect) } \\
\text { Alternative }\end{array}$ & $\begin{array}{c}\text { Cross-section } \\
\text { One-sided }\end{array}$ & $\begin{array}{c}\text { Period } \\
\text { One-sided }\end{array}$ & Both \\
\hline \hline Breusch-Pagan & 43.55246 & 0.008410 & 43.56087 \\
Honda & $(0.0000)$ & $(0.9269)$ & $(0.0000)$ \\
& 6.599429 & -0.091704 & 4.601656 \\
King-Wu & $(0.0000)$ & $(0.5365)$ & $(0.0000)$ \\
& 6.599429 & -0.091704 & 2.538193 \\
GHM & $(0.0000)$ & $(0.5365)$ & $(0.0056)$ \\
& -- & -- & 43.55246 \\
& -- & -- & $(0.0000)$ \\
\hline \hline
\end{tabular}

Sumber: Data diolah E-views 10

Berdasarkan hasil uji Lagrange Multiplier dengan metode breusch-pagan dimana diperoleh nilai $p$-value breusch-pagan sebesar 0,0000 artinya nilai tersebut $(0,0000<0,05)$ lebih kecil dari sig 0,05 , maka $\mathrm{H} 0$ ditolak dan menerima $\mathrm{H} 1$ yang berarti yaitu model yang tepat adalah random effect model. 
Jurnal Progres Ekonomi Pembangunan (JPEP)

Volume 4, Nomor 2, Tahun 2019

Page: $67-80$

http://ojs.uho.ac.id/index.php/JPEP

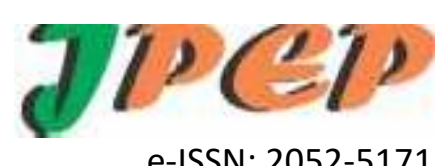

e-ISSN: 2052-5171

Uji Hausman Test

Uji hausman digunakan untuk membandingkan antara model fixed effect dengan random effect. Uji Hausman dilakukan dengan hipotesis sebagai berikut:

H0 : Memilih Random Effect Model, apabila nilai chi- squarenya $>\alpha 5 \%$.

H1 : Memilih Fixed Effect Model, apabila nilai chi-squarenya $<\alpha 5 \%$.

Tabel 5.10 Uji Hausman Test

\begin{tabular}{lccc}
\hline Test Summary & Chi-sq. Statistic & Chi-sqd.f & prob \\
\hline Cross-section random & 2.168920 & 2 & 0.3381 \\
\hline
\end{tabular}

\section{Sumber: Data diolah E-views 10}

Berdasarkan Tabel diatas, dimana diperoleh untuk nilai chi-squares sebesar 2.168920, sedangkan untuk nilai probabilitasnya 0,4565> 0,05, artinya dalam hal ini $\mathrm{H} 1$ ditolak dan $\mathrm{H} 0$ diterima, sehingga utuk pemilihan model yang akan tepat untuk digunakan pada penelitian ini yaitu model Random Effect Models (REM).

Model Analisis RegresI Random Effect Models (REM).

Berdasarkan hasil olah data, dimana dalam pengujian untuk penentuan pemilihan model, dengan uji Hausman Test, maka model yang tepat untuk digunkan dalam penelitian ini adalah Random Effect Models (REM).

Tabel 5.11 Hasil Estimasi Random Effect Models

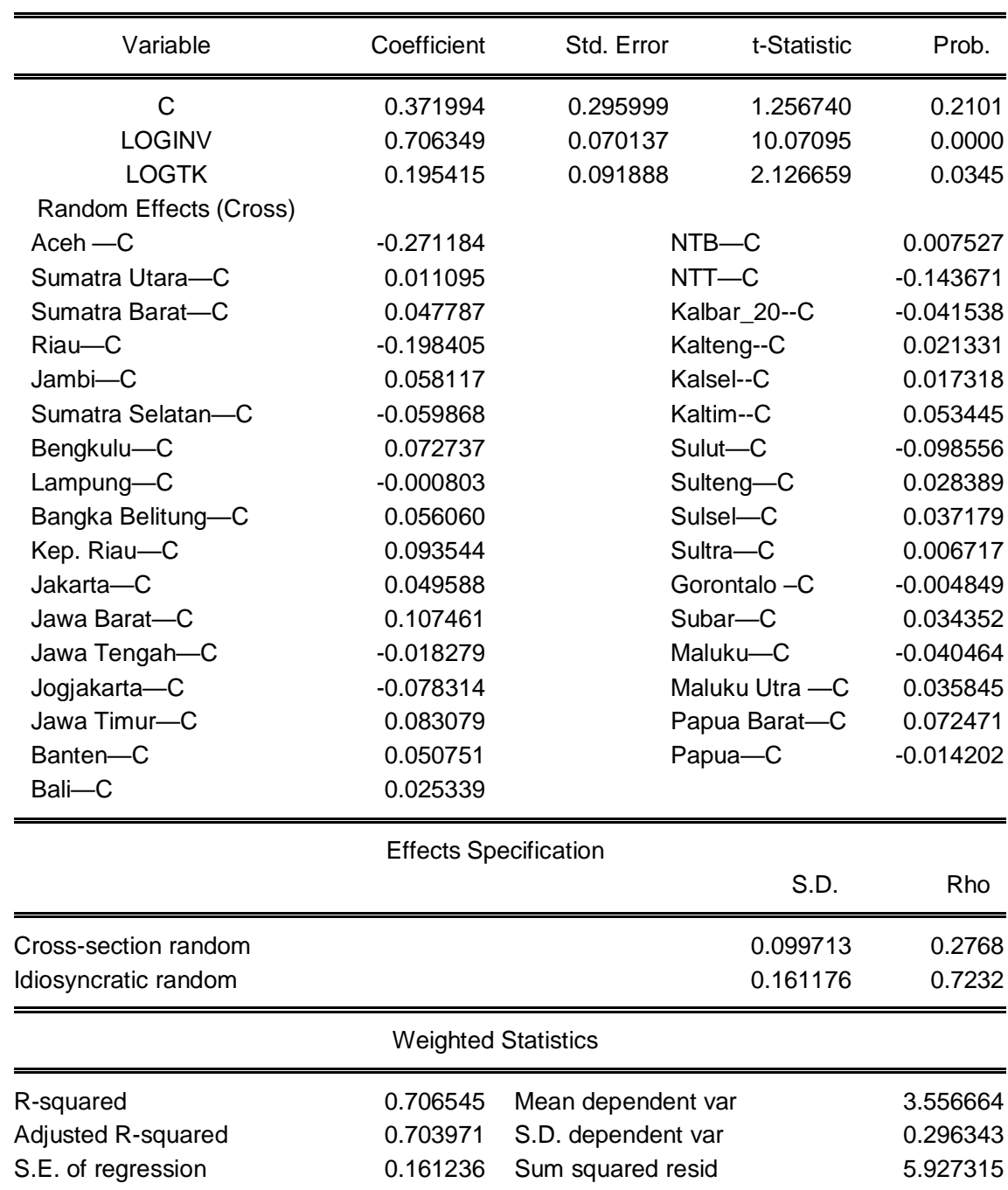


Jurnal Progres Ekonomi Pembangunan (JPEP)

Volume 4, Nomor 2, Tahun 2019

Page: $67-80$

http://ojs.uho.ac.id/index.php/JPEP

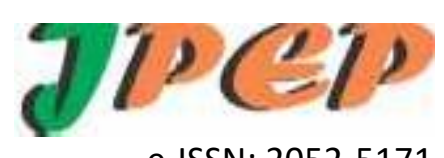

e-ISSN: 2052-5171

\begin{tabular}{llll} 
F-statistic & 274.4751 & Durbin-Watson stat & 2.072944 \\
Prob(F-statistic) & 0.000000 & & \\
\hline \hline & Unweighted Statistics & \\
\hline \hline R-squared & 0.865668 & Mean dependent var & 6.822113 \\
Sum squared resid & 8.019171 & Durbin-Watson stat & 1.532202 \\
\hline
\end{tabular}

\section{Sumber: Data diolah E-views 10}

Berdasarkan hasil regresi dengan Random Effect Models (RAM), maka diperoleh nilai koefisien regresi untuk setiap variabel penelitian sehingga diperoleh dengan persamaan sebagai berikut.

Hasil persamaan regresi antara investasi (PMTB) dan tenaga kerja yang mempengaruhi pertumbuhan ekonomi antar provinsi di indonesia sebagai berikut:

$\operatorname{LogPE}_{i t}=\alpha_{i}+B_{1} \operatorname{LogINV}{ }_{i t}+\beta_{2} \operatorname{LogTK}_{i t}+$ Uit $_{i t}$

Berdasarkan hasil analisis diatas maka dapat di tuliskan model persamaannya sebagai berikut:

$\log * P E=0,371994+0,706349 * \log I N V+0,195415 * \log T K+e$

Dari persamaan tersebut, dapat diinterpertasikan sebagai berikut:

1. Nilai constanta sebesar 0,371994 , artinya apabila diasumsikan variabel investasi dan tenaga kerja dianggap konstan, maka pertumbuhan ekonomi akan bertambah sebesar 0,371994\%

2. Koefisien regresi investasi sebesar 0,706349 artinya apabila variabel tenaga kerja diasumsikan konstan maka setiap kenaikan investasi sebesar $1 \%$ maka pertumbuhan ekonomi akan bertambah sebesar 0,706349\%.

3. Koefisien regresi tenaga kerja sebesar 0,195415 dapat diartikan apabila variabel investasi diasumsikan konstan maka setiap pertambahan tenaga kerja sebesar $1 \%$ maka pertumbuhan ekonomi akan meningkat sebesar $0,195415 \%$.

Berdasarkan model analisis Random Effect Models (REM), maka didapatkan untuk nilai constanta untuk masing-masing provinsi di Indonesia, sehingga untuk model persamaan masing-masing provinsi sebaga berikut:

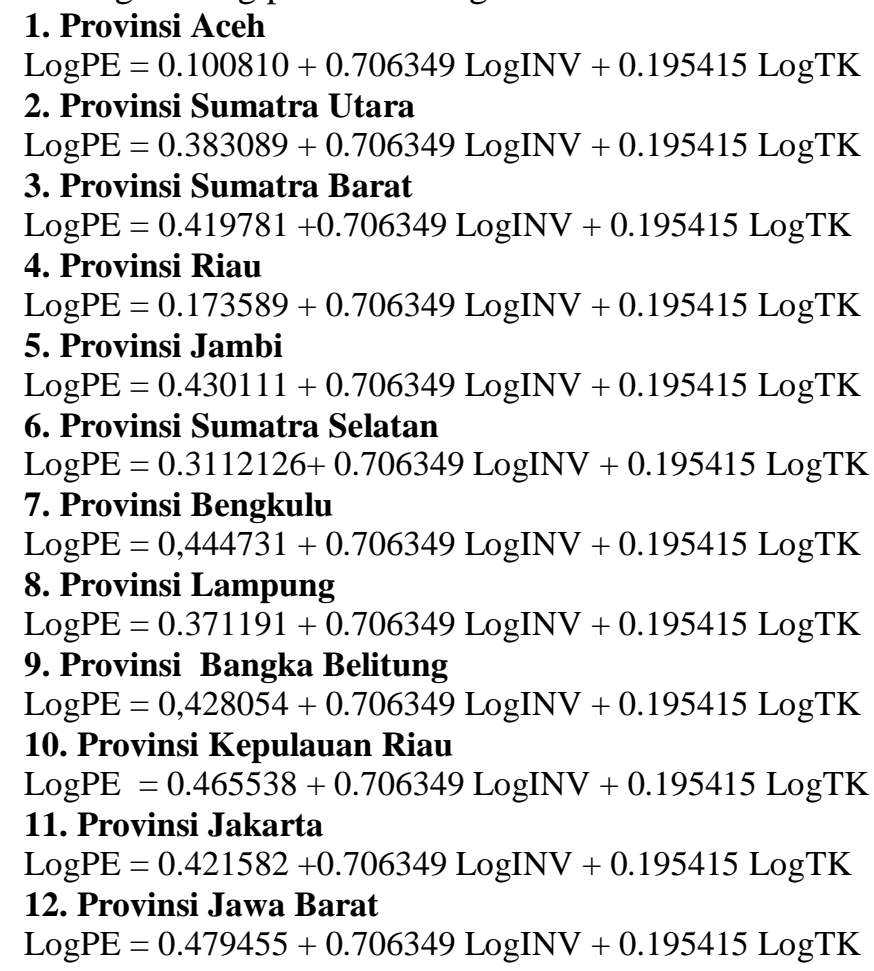


Jurnal Progres Ekonomi Pembangunan (JPEP)

Volume 4, Nomor 2, Tahun 2019

Page: 67-80

http://ojs.uho.ac.id/index.php/JPEP

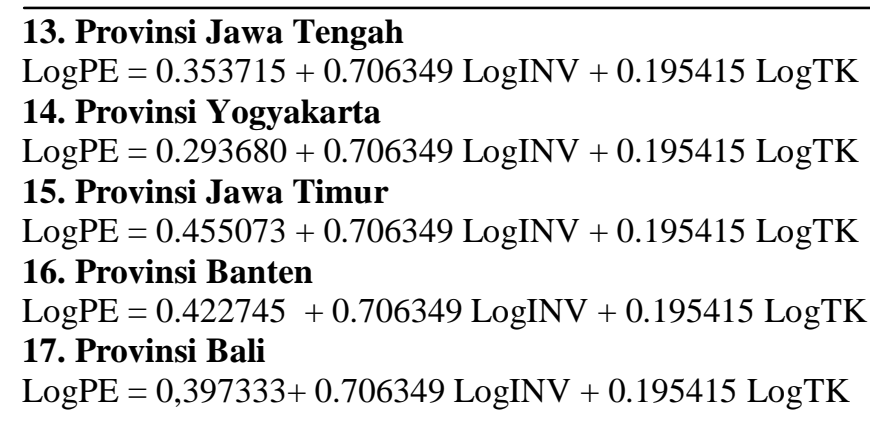

18. Provinsi Nusa Tenggara Barat

$\log P E=0,379521+0.706349 \operatorname{LogINV}+0.195415 \log T \mathrm{~K}$

19. Provinsi Nusa Tenggara Timur

$\log P E=0,228323+0.706349 \operatorname{LogINV}+0.195415 \log T K$

20. Provinsi kalimantan Barat

$\log P E=0.330456+0.706349 \log I N V+0.195415 \log T K$

21. Provinsi Kalimantan Tengah

$\log P E=0.393325+0.706349 \operatorname{LogINV}+0.195415 \log T K$

22. Provinsi Kalimantan Selatan

$\operatorname{LogPE}=0.389312+0.706349 \log \mathrm{INV}+0.195415 \log \mathrm{TK}$

23. Provinsi Kalimantan Timur

$\operatorname{LogPE}=0.425439+0.706349 \operatorname{LogINV}+0.195415 \log \mathrm{TK}$

24. Provinsi Sulawesi Utara

$\log P E=0,273438+0.706349 \log I N V+0.195415 \operatorname{LogTK}$

25. Provinsi Sulawesi Tengah

$\operatorname{LogPE}=0.400383+0.706349 \operatorname{LogINV}+0.195415 \operatorname{LogTK}$

26. Provinsi Sulawesi Selatan

$\log P E=0.409173+0.706349 \log I N V+0.195415 \log T K$

27. Provinsi Sulawesi Tenggara

$\log P E=0.378711+0.706349 \operatorname{LogINV}+0.195415 \log \mathrm{TK}$

28. Provinsi Gorontalo

$\operatorname{LogPE}=0.367145+0.706349 \log I N V+0.195415 \log T K$

29. Provinsi Sulawesi Barat

$\log P E=0.406346+0.706349 \operatorname{LogINV}+0.195415 \log T K$

30. Provinsi Maluku

$\operatorname{LogPE}=0.331530+0.706349 \log \mathrm{INV}+0.195415 \log \mathrm{TK}$

31. Provinsi Maluku Utara

$\operatorname{LogPE}=0.407839+0.706349 \operatorname{LogINV}+0.195415 \log \mathrm{TK}$

32. Provinsi Papua Barat

$\log P E=0.444465+0.706349 \log I N V+0.195415 \log T K$

33. Provinsi Papua

$\log P E=0.357792+0.706349 \log I N V+0.195415 \log T K$

Berdasarkan persamaan diatas, maka diperoleh nilai constanta untuk masing masing Provinsi, dimana untuk nilai constanta tertinggi yaitu, Jawa Barat sebesar 0.479455, Kep. Riau sebesar 0.465538, Jawa Timur sebesar 0,455073, Bengkulu sebesar 0,444731, Papua Barat sebesar 0,444465, Jambi 0,430111, kemudian menyusul Provinsi lain. Sementara nilai costanta terendah yaitu provinsi aceh sebesar, 0.100810 .

\section{Pengujian Hipotesis}

\section{Koefisien Determinasi ( $R$-Squared)}

Pengujian ini bertujuan untuk mengukur persentase dari variasi total variabel dependent yang mampu dijelaskan oleh model regresi. Perhitungan dimaksudkan untuk mengetahui ketepatan yang baik dalam analisis yang ditunjukkan oleh besarnya koefisien determinasi Adjusted $R$ - squared berikut: 
Jurnal Progres Ekonomi Pembangunan (JPEP)

Volume 4, Nomor 2, Tahun 2019

Page: $67-80$

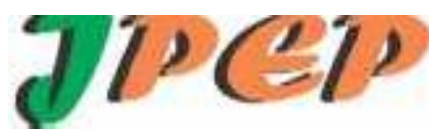

http://ojs.uho.ac.id/index.php/JPEP

Tabel 5.12 Perhitungan R-Squared ( $\left.\mathbf{R}^{2}\right)$

\begin{tabular}{|l|l|}
\hline R-squared & 0.706545 \\
\hline Adjusted R-squared & 0.703971 \\
\hline F-statistic & 274.4751 \\
\hline Prob(F-statistic) & 0.000000 \\
\hline
\end{tabular}

Sumber: Data diolah E-views 10

Dari hasil estimasi didapatkan bahwa besarnyaAdjusted $R$-squared yaitu 0.703971 . Artinya variabel independen yang terdiri dari investasi (PMTB) dan tenaga kerja mampu menjelaskan variabel dependen (pertumbuhan PDRB) sebesar 70,39\% sedangkan sisanya sebesar $29,61 \%$ dijelaskan variabel lain diluar model.

\section{Uji Simultan (Uji F)}

Uji $F$ dilakukan untuk mengetahui signifikan atau tidaknya variabel-variabel independen terhadap variabel dependen secara simultan (bersama-sama) dengan membandingkan nilai sig $\mathrm{f}$ dan nilai $\alpha 5 \%$ atau $(0,05)$. Dari hasil estimasi didapatkan bahwa untuk $f$ hitung sebesar 274.4751 dan nilai Probabilitas(F-statistik) yaitu sebesar 0,000000.Sehingga Probabilitas (F-statistik) lebih kecil dari $\alpha=5 \%(0,00000<0,05)$. Artinya model ini layak dan variabel independen yang terdiri dari investasi (PMTB) dan tenaga kerja secara bersama-sama (simultan) berpengaruh terhadap variabel dependen(pertumbuhan PDRB) antar provinsi di Indonesia tahun 2011-2017.

\section{Uji Parsial (Uji t)}

Uji t (parsial) dilakukan untuk mengetahui signifikan atau tidaknya masing-masing variabel independen terhadap variabel dependent secara individu. Dari hasil estimasi regresi data panel dengan Random Effect Models(REM) dapat di lihat uji parsial masing-masing variabel bebas terhadap variabel terikat.

\section{A. Variabel Investasi (PMTB)}

Dari hasil estimasi, didapatkan hasilnya t-hitung sebesar 10,07095dan jika dilihat dari besarnya nilai probabilitas investasi (PMTB) yaitu 0,0000. Sehingga probabilitas investasi lebih kecil dari $\alpha 5 \%(0.0000<0,05)$ maka disimpulkan bahwa variabel investasi (PMTB) memiliki pengaruh yang signifikan dan juga berpengaruh positif terhadap pertumbuhan ekonomi yang ditunjukkan dengan koefisien regresi sebesar 0,706349. Nilai koefisien regresi sebesar 0,706349, artinya apabila variabel tenaga kerja diasumsikan constan, maka setiap kenaikan investasi sebesar 1\%, maka pertumbuhan ekonomi meningkat sebesar 0,706349\%.

\section{B. Variabel Tenaga Kerja}

Berdasarkan hasil estimasi, didapatkan hasilnya t-hitung sebesar 2,126659dan jika dilihat dari besarnya nilai probabilitas tenaga kerja yaitu 0,0345 . Sehingga probabilitas tenaga kerja lebih kecil dari $\alpha 5 \%(0.0345<0,05)$, sedangkan untuk koefisien regresi tenaga keja yaitu sebesar 0,195415, maka dapat disimpulkan bahwa variabel tenaga kerjamemiliki pengaruh yang signifikan dan positifterhadap pertumbuhan ekonomi. Nilai koefisien regresi sebesar 0,195415, artinya apabila variabel investasi diasumsikan constan, maka setiap kenaikan tenaga kerja sebesar $1 \%$, maka pertumbuhan ekonomi meningkat sebesar $0,195415 \%$.

\section{Hasil Pembahasan}

Kajian utama penelitian ini adalah tentang pertumbuhan ekonomi (Pertumbuhan PDRB), dimana variabel yang digunakan untuk melihat faktor-faktor yang mempengaruhi pertumbuhan ekonomi yaitu variabel investasi (PMTB) danvariabel tenaga kerja, dengan menggunakan Random Effect Models (REM). 
Jurnal Progres Ekonomi Pembangunan (JPEP)

Volume 4, Nomor 2, Tahun 2019

Page: 67-80

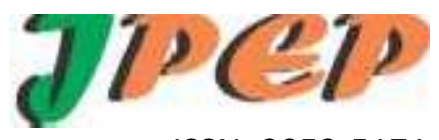

http://ojs.uho.ac.id/index.php/JPEP

\section{Analisis Pengaruh Investasi (PMTB) Terhadap Pertumbuhan Ekonomi di Provinsi Indonesia Tahun 2011-2012.}

Berdasarkan hasil regresi, dimana diperoleh koefisien regresi variabel investasi (PMTB) yaitu sebesar 0,706349 dengan nilai t-hitung sebesar 10,07095 dan nilai probabilitas sebesar 0,0000 pada $\alpha=0,05$. Artinya nilai sig. Probability $0,0000<0,05$, hal ini tersebut menunjukan bahwa variabel investasi memiliki pengaruh positif dan signifikan terhadap pertumbuhan ekonomi, artinya apabila variabel tenaga kerja diasumsikan constan, maka setiap kenaikan investasi sebesar $1 \%$, maka pertumbuhan ekonomi bertambah sebesar $0,706349 \%$.

Perkembangan investasi di Indonesia yang terdiri 33 provinsi mulai tahun 2011-2017 mengalami perkembangan dengan trend positif, hal ini dapat dilihat dengan perkembangan investasi dari 33 Provinsi di Indonesia pada tahun 2011 sebesar Rp 1.575.580.242,04 (Juta), kemudian sampai pada tahun 2017, perkembangan investasi meningkat sebesar Rp 2.258.552.760,71, hal serupa dengan perkembangan pertumbuhan ekonomi dimana untuk jumlah pertumbuhan ekonomi pada tahun 2011 sebesar Rp 422.525.894,17 dan kemudian mengalami pertumbuhan sampai pada tahun 2017, dimana total pertumbuhan ekonomi pada tahun 2017 menjadi sebesar 536.347.478,06 (Juta)

Hasil penelitian ini menunjukan bahwa Investasi memiliki pengaruh positif dan signifikan terhadap peningkatan pertumbuhan ekonomi (pertumbuhan PDRB), artinya kenaikan investasi (PMTB) mampu mendorong peningkatan pertumbuhan ekonomi (pertumbuhan PDRB). Hasil penelitian ini sesuai dengan teori Harrord Domard (Rahardja, Manurung, 2008: 143), bahwa salah satu faktor yang mempengaruhi pertumbuhan ekonomi yaitu investasi, sebab investasi ini akan meningkatkan stok barang modal, yang pada akhirnya memungkinkan peningkatan output. Selanjutnya menurut teori Schumpeter (Sukirno, 2012:435), dimana teori ini menekankan tentang pentingnya peranan pengusaha di dalam mewujudkan pertumbuhan ekonomi. Dalam teori ini ditunjukan bahwa para pengusaha merupakan golongan yang akan terus menerus membuat pembaharuan atau inovasi dalam kegiatan ekonomi. Berbagai kegiatan ini memerlukan investasi baru, olehnya itu investasi mempunyai pengaruh positif dan sangat mempengaruhi pertumbuhan ekonomi

Berkaitan dengan hal tersebut, penelitian ini sama sesuai dengan penelitian yang dilakukan oleh Sari.T. Irmaya, 2017 dengan judul "Determinasi Pertumbuhan Ekonomi di Provinsi Lampung", dimana salah satu variabel independen yang digunakan yaitu investasi dan hasil penelitianya menunjukan bahwa investasi berpengaruh positif dan signifikan terhadap pertumbuhan ekonomi. selain peneitian tersebut, Penelitian yang dilakukan I Made Yudhistira. I Gede Sujana Budhiasa (2012) dengan judul analisis pengaruh konsumsi, investasi dan inflasi terhadap Produk Domestik Bruto di Indonesia, dimana hasil peneltian serupa dengan hasil penelitian ini yang dimana investasi memiliki pengaruh positif dan signifikan terhadap pertumbuhan ekonomi.

\section{Analisis Pengaruh Tenaga Kerja Terhadap Pertumbuhan Ekonomi di Provinsi Indonesia Tahun 2011-2017.}

Berdasarkan hasil analisis regresi yang dilakukan dapat dijelaskan bahwa variabel tenaga kerja memiliki pengaruh positif dan signifikan terhadap pertumbuhan ekonomi di Provinsi Indonesia Tahun 2011-2017, dengan hasil koefisien positif tenaga kerja sebesar 0,195415 dan nilai $\mathrm{p}$-value $0,0345<0,05$, hal ini sesuai dengan hipotesis penelitian yang menyatakan bahwa variabel tenaga kerja memiliki pengaruh signifikan dan positif terhadap pertumbuhan ekonomi di Provinsi Indonesia Tahun 2011-2017. Nilai koefisien sebesar 0,195465 artinya ketika terjadi pertambahan tenaga kerja sebesar $1 \%$ maka pertumbuhan ekonomi (pertumbuhan PDRB) akan meningkat sebesar 0,195465\%. 
Jurnal Progres Ekonomi Pembangunan (JPEP)

Volume 4, Nomor 2, Tahun 2019

Page: $67-80$

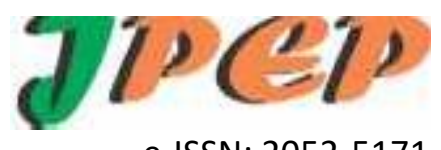

http://ojs.uho.ac.id/index.php/JPEP

Perkembangan tenaga kerja di Indonesia mulai tahun 2011-2017 mengalami pertumbuhan dengan trend positif, dimana pada tahun 2011, tenaga kerja yang kategori bekerja yaitu berjumlah 107.416.309 orang, kemudian meningkat pada tahun 2012 menjadi 112.504.868 orang dan sampai tahun 2017 menjadi 120.710 .007 orang, disisi lain perkembangan pertumbuhan ekonomi mengalami peningkatan mulai tahun 2011-2013, dimana jumlah pertumbuhan ekonomi pada tahun 2011 sebesar Rp 422.525.894,17 dan kemudian mengalami pertumbuhan sampai pada tahun 2017, dimana total pertumbuhan ekonomi pada tahun 2017 menjadi sebesar 536.347.478,06 (Juta).

Hasil penelitian ini menujukan bahwa tenaga kerja dapat meningkatkan pertumbuhan ekonomi. Hal ini sesuai dengan teori kaum klasik yang menyatakan salah satu faktor yang mempengaruhi pertumbuhan ekonomi adalah jumlah penduduk. Menurut penjelasan Adam Smith (Murni. Asfia, 2016: 195), bahwa peningkatan output akan berkembang sejalan perkembangan penduduk, artinya pertambahan penduduk merupakan salah satu faktor yang dapat meningkatkan pertumbuhan ekonomi.

Sama halnya dalam Teori Penduduk Optimum dimana teori ini juga merupakan teori pertumbuhan ekonomi klasik yang menjelaskan bahwa pertambahan total produk itu akan terjadi jika pertambahan tenaga kerja diikuti dengan pertambahan modal artinya dalam teori ini menjelaskan bahwa tenaga kerja merupakan salah satu unsur yang dapat meningkatkan pertumbuhan ekonomi (Murni. A, 2016: 195).

Hasil penelitian ini juga sesuai dengan penelitian yang dilakukan oleh Supartoyo, Yessi. H (2013) dengan judul yaitu "(The Economic Growth and The Regional Characteristics: The Case of Indonesia), dimana salah satu variabel yang digunakan yaitu angkatan kerja dan untuk hasil penelitiannya menjelaskan bahwa variabel angkatan kerja berpengaruh positif dan signifikan terhadap pertumbuhan ekonomi. Selain penelitian tersebut, penelitian lain yang serupa dengan hasil penelitian ini yaitu penelitian yang dilakukan oleh Sari.T. Irmaya, 2017 dengan judul "Determinasi Pertumbuhan Ekonomi di Provinsi Lampung", dimana salah satu variabel independen yang digunakan yaitu investasi dan hasil penelitiannya juga menunjukan bahwa investasi berpengaruh positif dan signifikan terhadap pertumbuhan ekonomi.

\section{KESIMPULAN DAN SARAN}

\section{Kesimpulan}

Berdasarkan hasil penelitian dan pembahasan tentang Analisis Pertumbuhan Ekonomi Antar Provinsi Di Indonesia Tahun 2011-2017, dimana penelitian ini dilakukan unutk melihat pengaruh variabel investasi dan tenaga kerja terhadap pertumbuhan ekonomi, dengan menggunakan data panel 2011-2017 pada 33 provinsi di Indonesia. Dengan menggunakan regresi linear berganda pendekatan Random Effect Models (REM), maka dapat disimpulkan sebagai berikut:

1. Investasi berpengaruh terhadap pertumbuhan ekonomi antar provinsi di Indonesia. Peningkatan investasi tersebut akan berdampak terhadap peningkatan pertumbuhan ekonomi, artinya semakin tinggi peningkatan investasi maka akan berpengaruh terhadap peningkatan pertumbuhan ekonomi.

2. Tenaga kerja berpengaruh terhadap pertumbuhan ekonomi antar provinsi di Indonesia, semakin tinggi pertumbuhan tenaga kerja maka pertumbuhan ekonomi meningkat pula. Peningkatan tenaga kerja tersebut disimpulkan dapat memberikan kontribusi terhadap peningkatan pertumbuhan ekonomi.

3. Nilai constanta masing-masing provinsi sangat bervariasi, untuk nilai constanta yang tertinggi yaitu Provinsi Jawa Barat sebesar 0,479455, sedangkan nilai constanta yang paling terendah dari 33 provinsi adalah Provinsi Aceh sebesar, 0,100810.

\section{Saran}

1. Pemerintah disetiap provinsi Indonesia, dimana ketika dalam pengambilan kebijakan terkait dengan penanganan dalam upaya peningkatan pertumbuhan ekonomi perlu 
Jurnal Progres Ekonomi Pembangunan (JPEP)

Volume 4, Nomor 2, Tahun 2019

Page: $67-80$

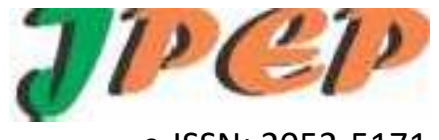

http://ojs.uho.ac.id/index.php/JPEP

mempertimbangkan mengenai peningkatan investasi dan pertumbuhan tenaga kerja yang dapat berdampak terhadap peningkatan pertumbuhan ekonomi.

2. Pemerintah disetiap provinsi Indonesia, perlu memperhatikan dan mengevaluasi hal-hal yang terkait dengan masalah kebijakan tenaga kerja, supaya kebijakan tenaga kerja ini dapat memberikan kontribusi terhadap pertumbuhan ekonomi.

3. Bagi peneliti selanjutnya yang akan melakukan penelitian yang serupa dengan penelitian ini agar sekiranya dapat menambah variabel-variabel lain yang belum masuk dalam penelitian ini.

\section{DAFTAR PUSTAKA}

Ambarini. Lestari. 2015. Ekonomi Publik: Penerbit IN Media Bogor.

Agus Winarendra. 2014. Analisis Tingkat Kemiskinan Dan Faktor-Faktor YangMempengaruhi (Kasus: 35 Kabupaten/Kota Di JawaTengah Tahun 2008- 2012). Ekonomika dan Bisnis/ Ilmu Ekonomi Studi Pembangunan.

Artoyo. AR. 1999. Tenaga Kerja Perusahaan : Pengertian dan Peranannya.Jakarta :Balai Pustaka, Jakarta.

Badan Pusat Statitik (BPS). 2018. Pendapatan Nasional Indonesia" National Income Of Indonesia 2013-2017.

Badan Pusat Statitik (BPS). 2018. Produk Domestik Bruto (PDRB) Indonesia Berdasarkan Pengeluaran 2013-2017.

Basuki. A. T, Imamuddin Yuliadi. 2015, Ekonometrika Teori \& Aplikasi. Mitra Pustaka Nurani, Yogyakarta.

Direktorat Jendral Bea Dan CUKAI Kementrian Keuangan. 2016.

Ghozali Imam. 2005. Aplikasi Multivariate Dengan Program SPSS Edisi Ketiga. Badan Penerbit Universitas Diponegoro, Semarang.

Ginting. Ari Mulianta. 2017. jurnal "Analisis pengaruh ekspor terhadap pertumbuhan ekonomi indonesia. Pusat penelitian, sekertariat jendral dan badan keahlian DPR Republik Indonesia. Jakarta, 10207, Indonesia.

Gujarati, D.N. 2011. Dasar-Dasar Ekonometrika. Terjemahan Mangunsong R.C.

Sugiyono. 2008. Metode Penelitian Bisnis. Alfabeta, Bandung.

Henry Faizal Noor. 2015. Ekonomi Publik. Penerbit Indeks Jakarta.

Jhingan. M.L 2003. Ekonomi Pembangunan dan Perencanaan, Jakarta: Raya Grafindo Persada.

Larasasti. IS, Sulasmyati. S 2018 "Pengaruh Inflasi, Ekspor, Dan Tenaga Kerja Terhadap Produk Domestik Bruto "Jurnal Administrasi Bisnis (JAB)|Vol. 63 No. 1 Oktober.

Mankiw. N. Gregory. 2006. Makro Ekonomi. Penerbit Erlangga Edisi Keenam. Jakarta.

Mulyadi. S. 2012. Ekonomi Sumber Daya Manusia Dalam Prespektif Pembangunan. : PT. Raja grafindo Persada, Jakarta.

Murni Asfia. 2016. Ekonomika Makro. PT Refika Aditima, Bandung

Pambudi. Eko Wicaksono. 2013. Analisis Pertumbuhan Ekonomi Dan Faktor-Faktor Yang Mempengaruhinya (Kabupaten /Kota Provinsi Jawa Tengah), Dipanegoro Journal Of Economics, Volume 2, Nomor 2, Tahun 2013.

Paul. A. Samulson, William D Nordhaus, 2001 Ilmu Ekonomi Makro. PT Media Global Edukasi Jakarta.

Rahardja. P, Manurung. M. 2008. Teori Ekonomi Makro. Fakultas Ekonomi Universitas Indonesia, Jakarta.

Rosydi Suherman. 2009. Pengantar Teori Ekonomi Makro"Pendekatan Kepada Teori Mikro Dan Makro. ED. Revisi, CET 8. Rajawali Pers, Jakarta.

Rustiano. 2008. Analis Pengaruh Investasi, Tenaga Kerja Dan Pengeluaran Pemerintah Terhadap Pertumbuhan Ekonomi Dipropinsi Jawa Tengah. Tesis ini tidak dipublikasikan. 
Jurnal Progres Ekonomi Pembangunan (JPEP)

Volume 4, Nomor 2, Tahun 2019

Page: $67-80$

http://ojs.uho.ac.id/index.php/JPEP

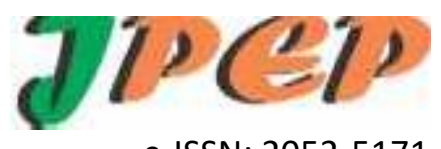

e-ISSN: 2052-5171

Sari. T. Irmaya. 2017. Determinan Pertumbuhan Ekonomi di Provinsi Lampung Tahun 20002015. Tesis ini tidak di publikasikan

Sukirno. Sadono. 2012. Makro Ekonomi Teori Pengantar. Rajawali Pers. Jakarta.

Supartoyo. Yesi Hendriani. 2013. The Economic Growth and The Regional Characteristics: The Case of Indonesia. Sekolah Pasca Sarjana Institut Pertanian Bogor.

Tarigan. Robinson. 2012. Ekonomi Ekonomi Regional, Teori dan Aplikasi. PT. Bumi Aksar. Jakarta:

Tasrif. M. 2019. Analisis Pertumbuhan Ekonomi Antar Provinsi di Indonesia. Tesis ini tidak dipublikasikan.

Taufik. Muhamad. 2011. Pengaruh Investasi Dan Ekspor Terhadap Pertumbuhan Ekonomi Serta Penyerapan Tenaga Kerja Di Provinsi Kalimantan Timur"JEKT. 7 (20) : 90-101. ISNN: 2301-8968.

Yudisthira, Budhiasa. 2012. Analisi Pengaruh Konsumsi, Investasi, Dan Inflasi Terhadap Produk Domestik Bruto Di Indonesia Tahun 2000-2012” E Jurnal Ep Unud, 2 (11) : 492 501, ISNN: 2303-0178.

Widarjono. Agus. 2007. Ekonometrika Teori dan Aplikasi Untuk Ekonomi dan Bisnis Edisi Kedua. Ekonomia, Yogyakarta. 